maximum of the annual cycle of phytoplankton production. It is particularly interesting to note, however, that even in these high latitudes $\left(77^{\circ} \mathrm{S}\right.$.) the phytoplankton seem to show a diurnal variation in pigment content and photosynthetic ability, although this is evidently less marked than in the tropics.

The fourth paper deals with the systematic composition of the phytoplankton in the Weddell Sea and it appears that diatoms predominated in the populations. The Tintinnids are also dealt with and the following paper examines the distribution of Radiolaria, this time in bottom sediments. These are examined in the light of the geological history of Antaretic seas, as their distribution is closely influenced by the Antarctic Convergence. The onset of glaciation in Antarctica may have intensified the circulation, and thus affected the distribution of the fauna.

The final three papers in the volume deal diversely with midwater fishes and monogenetic trematodes, respectively from the Peru-Chile trench and New Zealand waters. The distribution of fish taken in Isaacs Kidd trawls in the Peru-Chile trench shows a faunal boundary at about $20^{\circ} \mathrm{S}$., which affects some 20 per cent of the species present other species evidently extend from tropical waters into the Antarctic. The monogenetic trematodes were collected from fish and several new species are described. The family Microcotylinae is completely reviewed.

The papers in this book cover diverse fields, but they exemplify some of the present activity in biological work in Antarctic seas and show the application of new techniques which are beginning to answer some of the prob. lems posed by earlier studies. The papers from adjacent waters emphasize the continuity of the Southern Ocean and its biology with the adjacent seas to the north and show an important appreciation of the need to look at the polar waters not as an isolated entity but as a boundary region of the world's ocean.

R. I. CURRIE

\section{ECOLOGY OF DIPTEROCARP FORESTS}

\section{Ecological Studies in the Mixed Dipterocarp Forests of Brunel State}

By P. S. Ashton. (Oxford Forestry Memoirs, No. 25.) Pp. $75+37$ plates +17 tables +70 figures. (Oxford: Clarendon Press; London: Oxford University Press, 1964.) 45s. net.

THE extensive lowland forests of the small state of Brunei in Borneo are rich in Dipterocarpaceae, which is the principal timber producing family of the area. The richness of the Brunei forests is demonstrated by the estimated 2,000 species of tree which exceed 12 in. in girth in the forests of Brunei. Until Dr. Ashton's studies in Brunei, the immense floristic richness of the area had been practically unsampled, a situation which made the work of the ecologist especially difficult. As a specialist in the taxonomy of the Dipterocarpaceae, Dr. Ashton is well equipped to tackle the formidable complexities of the Dipterocarp forests, especially since it is possible for the specialist to recognize species of this family from foliage characters alone-even from fallen leaves on the forest floor. Three years of intensive field work laid the basis of this publication, and during this period some 30,000 trees were enumerated and 13,000 specimens collected. The author nevertheless emphasizes that this is only a preliminary survey of this neglected territory.

The most interesting point about the methods used is that a quantitative analysis of the Dipterocarp forests was carried out using coefficients of similarity between different stands-a method originally developed by Bray and Curtis for forests in Wisconsin. Two areas were chosen, one on clay rich soils and the other on sandy soils. An acre was taken as the basic size of a plot and fifty plots were studied in each area. Only trees more than $12 \mathrm{in}$. in girth were recorded, because the field and shrub layers, which consist mainly of saplings and seedlings, vary with the time since the last flowering of the trees above. An enormous amount of material is presented in the form of tables and figures, but much of this will only be understood by those already acquainted with the method used, and a previous knowledge of this is optimistically assumed.

Dr. Ashton emphasizes the important correlation between soils and the species which grow on them. Most species of Dipterocarpaceae seem to be restricted to certain soils. Special attention is therefore given to the soils of the Dipterocarp forests and other types of soil are mentioned for comparison. Differences in the soils are shown to affect the $p H$ of leaf extracts as well as the reactions produced by precipitating agents on the proteins of fresh leaf extracts. The altitudinal distribution of Dipterocarps, at least below about $1,300 \mathrm{~m}$, appears to be determined more by the soil than by other factors; anomalous altitudinal records of species result from the presence of suitable soils at those altitudes. Dr. Ashton therefore suggests that some "microtherm" species (as van Steenis has called them) may be confined to high altitudes on tropical mountains because their edaphic environment is confined to those regions. Edaphic factors in Brunei, as well as in Sarawak, have apparently obscured the altitudinal floristic zonation below $1,300 \mathrm{~m}$ such as that described by van Steenis for Java, where the floristic transitional zone coincides with edaphic transitions.

In classifying the forests Dr. Ashton found that the scheme applied by Symington to the Malayan forests in which main climax formations are distinguished does not apply to Brunei forests. A classification based on communities, although arbitrary for Brunei, appears to be the most useful type for practical purposes. A hierarchic system adopted from Braun-Blanquet criteria and based on fidelity and constancy rather than dominance is advocated.

There is an interesting discussion on the distribution of Dipterocarpaceae in relation to soils and geological history. Dr. Ashton opposes the view of Foxworthy and Merrill that the family originated in Borneo. The present abundance of Dipterocarp species in Borneo is considered a result of a secondary burst of evolution. Dr. Ashton supports Croizat's proposal that the Dipterocarps had an origin in Gondwanaland. The text ends with valuable recommendations on silviculture land use and especially on the establishment of permanent reserves in undisturbed primary forest for the purposes of future research and the conservation of rare species and for educational purposes. Three named areas are suggested for immediate preservation. It is to be hoped that these recommendations will not fall on deaf ears.

Dr. Ashton has produced a valuable and stimulating book on a highly complex subject. Several of the themes introduced deserve further development. He has demonstrated especially that the close correlation between the composition of rain forest and the underlying soils means that plant ecology, given a secure taxonomic basis, can be very important to surveys of the soils of large areas of jungle.

L. L. Forman

\section{Pests of Stored Products}

By J. W. Munro. (The Rentokil Library.) Pp. 234. (London: Hutchinson and Co. (Publishers), Ltd., 1966.) 42s. net.

THIs book, written by one of the first entomologists to acknowledge the importance of insect damage to stored products, is a fully illustrated account of the history and practice of pest control in this field. It directs attention to the effect of insect infestation on good-will in international trade and is of interest in tracing the development of this branch of economic entomology in Britain. It surveys steps taken abroad which have led, not only to a 